(C) 2020 by the Arizona Board of Regents on behalf of the University of Arizona. This is an Open Access article, distributed under the terms of the Creative Commons Attribution licence (http://creativecommons. org/licenses/by/4.0/), which permits unrestricted re-use, distribution, and reproduction in any medium, provided the original work is properly cited.

\title{
TESTING AND IMPROVING THE INTCAL20 CALIBRATION CURVE WITH INDEPENDENT RECORDS
}

\author{
Raimund Muscheler ${ }^{1 *}$ (D) Florian Adolphi ${ }^{1,2}$ - Timothy J Heaton ${ }^{3} \cdot$ \\ Christopher Bronk Ramsey ${ }^{4}$ (i) Anders Svensson ${ }^{5}$ - Johannes van der Plicht ${ }^{6}$ • \\ Paula J Reimer ${ }^{7}$ (1) \\ ${ }^{1}$ Quaternary Sciences, Department of Geology, Lund University, Lund, Sweden \\ ${ }^{2}$ Climate and Environmental Physics \& Oeschger Centre for Climate Change Research, Physics Institute, University of \\ Bern, Bern, Switzerland \\ ${ }^{3}$ School of Mathematics and Statistics, University of Sheffield, Sheffield, UK \\ ${ }^{4}$ Research Laboratory for Archaeology and the History of Art, University of Oxford, Oxford, UK \\ ${ }^{5}$ Niels Bohr Institute, Ice and Climate Research University of Copenhagen, Copenhagen, Denmark \\ ${ }^{6}$ Centrum voor Isotopen Onderzoek, Rijksuniversiteit Groningen, Nijenborgh, The Netherlands \\ ${ }^{7}{ }^{14} \mathrm{CHRONO}$ Centre for Climate, the Environment and Chronology, School of Natural and Built Environment, \\ Queen's University Belfast, Belfast, UK
}

\begin{abstract}
Connecting calendar ages to radiocarbon $\left({ }^{14} \mathrm{C}\right)$ ages, i.e. constructing a calibration curve, requires ${ }^{14} \mathrm{C}$ samples that represent, or are closely connected to, atmospheric ${ }^{14} \mathrm{C}$ values and that can also be independently dated. In addition to these data, there is information that can serve as independent tests of the calibration curve. For example, information from ice core radionuclide data cannot be directly incorporated into the calibration curve construction as it delivers less direct information on the ${ }^{14} \mathrm{C}$ age-calendar age relationship but it can provide tests of the quality of the calibration curve. Furthermore, ice core ages on ${ }^{14} \mathrm{C}$-dated volcanic eruptions provide key information on the agreement of ice core and radiocarbon time scales. Due to their scarcity such data would have little impact if directly incorporated into the calibration curve. However, these serve as important "anchor points" in time for independently testing the calibration curve and/or ice-core time scales. Here we will show that such information largely supports the new IntCal20 calibration record. Furthermore, we discuss how floating tree-ring sequences on ice-core time scales agree with the new calibration curve. For the period around 40,000 years ago we discuss unresolved differences between ice core ${ }^{10} \mathrm{Be}$ and ${ }^{14} \mathrm{C}$ records that are possibly related to our limited understanding of carbon cycle influences on the atmospheric ${ }^{14} \mathrm{C}$ concentration during the last glacial period. Finally, we review the results on the time scale comparison between the Greenland ice-core time scale (GICC05) and IntCal20 that effectively allow a direct comparison of ${ }^{14} \mathrm{C}$-dated records with the Greenland ice core data.
\end{abstract}

KEYWORDS: calibration, chronology, climate, dating, ice core.

\section{INTRODUCTION}

The building of a radiocarbon $\left({ }^{14} \mathrm{C}\right)$ calibration curve depends on the robust connection of atmospheric ${ }^{14} \mathrm{C}$ ages to calendar ages. This is best done by ${ }^{14} \mathrm{C}$ measurements in tree rings, as they take up carbon directly from the atmosphere and can be very precisely dated via dendrochronology. IntCal20 is therefore based only upon tree-ring ${ }^{14} \mathrm{C}$ measurements for approximately the last 14,000 years $(13,910$ calendar yr $\mathrm{BP}=$ calendar age relative to the standard year $1950 \mathrm{AD}$; Reimer et al. 2020 in this issue). These are dated via dendrochronology back to 12,310 calendar yr BP and extended via wiggle-match dating of the tree-ring ${ }^{14} \mathrm{C}$ data simultaneously to curve construction (Heaton et al. 2020 in this issue). Prior to this period there are only limited sections covered by tree-ring ${ }^{14} \mathrm{C}$ series whereby the relative tree ring counts within each series are known but the absolute age is not. Therefore, the calibration curve is based upon a wider range of sources including speleothems, marine records of corals and foraminifera, and macrofossils all of which need to be dated with other methods. The bulk of the data underlying IntCal20 for the older part (i) do not have the same temporal resolution as the tree-ring data, (ii) contain larger potentially systematic calendar age dating

\footnotetext{
*Corresponding author. Email: raimund.muscheler@geol.lu.se.
} 
Table 1 Summary of the dating results of the deposits from three volcanic eruptions and their ${ }^{14} \mathrm{C}$ results. See main text for details and references.

\begin{tabular}{|c|c|c|c|c|}
\hline Eruption & $\begin{array}{l}\text { Independent } \\
\text { dating method }\end{array}$ & $\begin{array}{l}\text { Independent } \\
\text { calendar age }\end{array}$ & $\begin{array}{l}{ }^{14} \mathrm{C} \text { age } \\
\text { (material) }\end{array}$ & $\begin{array}{c}\text { Calibrated age } \\
\text { range }(2 \sigma)\end{array}$ \\
\hline Towada-H & $\begin{array}{l}\text { Ice core layer counting } \\
\text { (GICC05 time scale) } \\
\text { (1502.45-1502.60m depth, } \\
\text { NEEM ice core) }\end{array}$ & $\begin{array}{c}15,656 \pm 226(2 \sigma) \\
\text { calendar yr BP }\end{array}$ & $\begin{array}{c}13,133 \pm 33(1 \sigma) \\
{ }^{14} \mathrm{C} \text { yr BP } \\
\text { (buried trees) }\end{array}$ & $\begin{array}{c}15,615-15,895 \\
\text { cal BP } \\
(\text { IntCal20) }\end{array}$ \\
\hline Oruanui & $\begin{array}{l}\text { Ice core layer counting } \\
\text { (WD2014 time scale) } \\
\text { (2660.3 m depth, WAIS } \\
\text { ice core) }\end{array}$ & $\begin{array}{l}25,318 \pm 250(2 \sigma) \\
\text { calendar yr BP }\end{array}$ & $\begin{array}{l}21,300 \pm 60(1 \quad \sigma) \\
{ }^{14} \mathrm{C} \text { yr BP } \\
\text { (buried branches and } \\
\text { twigs) }\end{array}$ & $\begin{array}{c}25,335-25,800 \\
\text { cal BP } \\
(\text { SHCal20) }\end{array}$ \\
\hline $\begin{array}{l}\text { Campagnian } \\
\text { Ignimbrite } \\
\text { (CI) }\end{array}$ & $\begin{array}{l}\text { Ar/Ar dating of sanidine } \\
\text { crystals from CI }\end{array}$ & $\begin{array}{l}39,850 \pm 140(2 \sigma) \\
\text { calendar yr BP }\end{array}$ & $\begin{array}{l}34,290 \pm 90(1 \sigma){ }^{14} \mathrm{C} \mathrm{yr} \\
\text { BP (charred wood } \\
\text { embedded in Tuff) }\end{array}$ & $\begin{array}{c}39,220-39,705 \\
\text { cal BP } \\
\text { (IntCal20) }\end{array}$ \\
\hline
\end{tabular}

uncertainties and (iii), in the case of speleothem and marine data, do not directly reflect the atmospheric concentrations. These challenges may also filter out some higher frequency components of atmospheric variation. Furthermore, the density of the available data reduces as we extend further back in time and, in some cases, the ${ }^{14} \mathrm{C}$ measurements contain relatively large uncertainties especially when going towards to the limits of the method when ${ }^{14} \mathrm{C}$ has largely decayed from the sample. As a consequence of these various issues, our overall estimate of the calibration curve before 13,910 calendar yr BP is less certain and it does not reflect the high-resolution fine structure that we know from the Holocene period and that we would expect to also be present in the older part. This can lead to biases in the calendar age determination of precisely dated ${ }^{14} \mathrm{C}$ samples for the last ice age. In the following we will discuss how independent comparison data relates to the IntCal20 calibration curve and how IntCal20 relates to the most recent icecore time scales.

\section{Volcanic Time Markers}

There are a number of volcanic eruptions that have very precise ${ }^{14} \mathrm{C}$ ages connected to them. For three of these events there are, in addition, also ${ }^{14} \mathrm{C}$-independent calendar age estimates connected to them (Table 1). Here we discuss how these ${ }^{14} \mathrm{C}$ age-calendar age relationships compare to IntCal20.

\section{Towada-H Eruption around 15,700 yr Ago}

Horiuchi et al. (2007) dated two subfossil tree stumps from a forest buried by the ash from the Towada Hachinohe (Towada-H) eruption in the northeastern part of Honshu Island, Japan. Dendrochronological analysis showed that many trees with bark remains were buried at the same time allowing for replicate ${ }^{14} \mathrm{C}$ measurements of the event (Horiuchi et al. 2007). The combined measurements of the 5 outermost rings of two tree stumps yielded a ${ }^{14} \mathrm{C}$ age of $13,133 \pm 33(1 \sigma){ }^{14} \mathrm{C}$ yr BP. The tephra from the Towada-H eruption has been found in the NEEM Greenland ice core (Bourne et al. 2016). The tephra layer in the NEEM ice core is dated to $15,656 \pm 226(2 \sigma)$ calendar yr BP $(=15,706 \pm 226 \mathrm{yr} b 2 \mathrm{k}$, b2 $\mathrm{k}=$ calendar date relative to $2000 \mathrm{AD}$ ) via ice core layer counting, the Greenland Ice Core Chronology 2005 (GICC05) (Rasmussen et al. 2006, 2013; Svensson et al. 2008). The ice core dating 


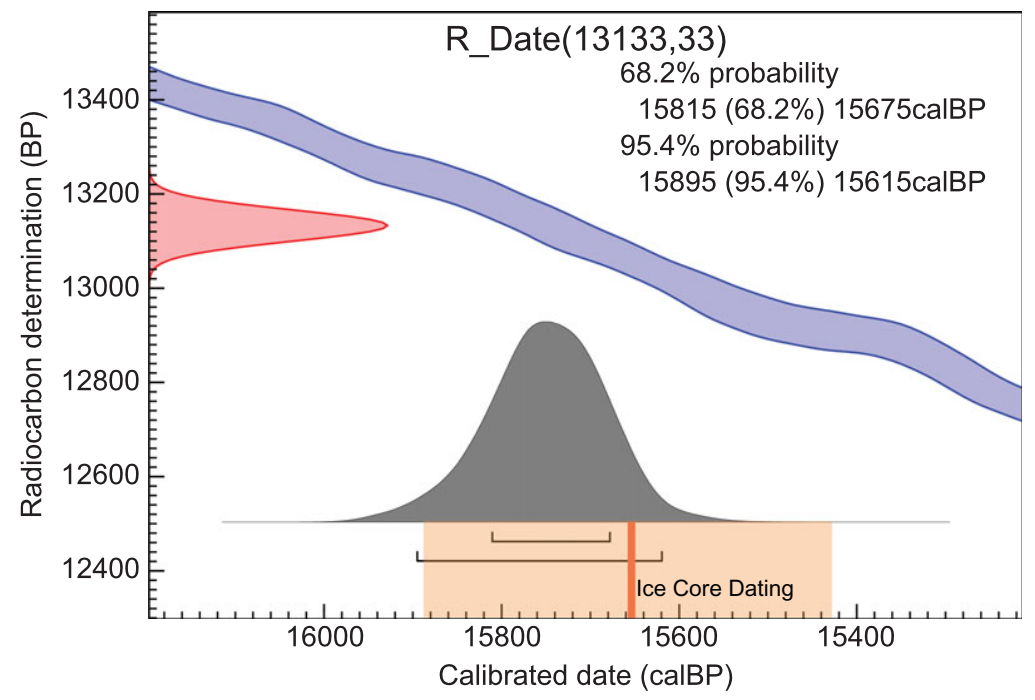

Figure 1 Relationship between ice core age (GICC05 time scale) (Rasmussen et al. 2006, 2013; Svensson et al. 2008) and the calibrated ${ }^{14} \mathrm{C}$ age of the Towada-H eruption in Japan (calibrated with the IntCal20 calibration curve).

uncertainty represents the maximum counting error (MCE) and is considered to encompass the $95 \%$ confidence interval.

Figure 1 shows that ice core age and calibrated ${ }^{14} \mathrm{C}$ age of Towada-H agree within the stated uncertainties. Nevertheless, the most likely ice core age slightly underestimates the ${ }^{14} \mathrm{C}$ dating calibrated with the new IntCal20 calibration curve by about 100 years, in agreement with the results by Adolphi et al. (2018).

\section{Oruanui Eruption around 25,500 yr Ago}

The Oruanui eruption from the Taupo volcano in New Zealand has been, similar to the Towada-H eruption, ${ }^{14} \mathrm{C}$-dated with high precision on material that was buried by the ash from the eruption (branches and macrofossils) (Vandergoes et al. 2013). Eight ${ }^{14} \mathrm{C}$ determinations could be directly connected to the age of the eruption and the errorweighted average is $21,300 \pm 60(1 \sigma){ }^{14} \mathrm{C}$ yr BP (Vandergoes et al. 2013). Similar to Towada-H, tephra from the Oruanui eruption has been found in the West Antarctic Ice Sheet (WAIS) ice core from Antarctica, geochemically identified and thereby linked to its source (Dunbar et al. 2017). It has been found at a depth of $2660.3 \mathrm{~m}$, which corresponds to an age of $25,318 \pm 250$ calendar yr BP (Sigl et al. 2016; Dunbar et al. 2017). The WAIS ice core chronology (WD2014) is based on annual layer counting down to a depth of $2850 \mathrm{~m}$ (Sigl et al. 2016).

Since the Oruanui eruption from Taupo volcano arises from the Southern Hemisphere, the organic material buried by the eruption needs to be calibrated against the SHCal20 curve (Hogg et al. 2020 in this issue). In this time period, the SHCal20 curve is essentially an offset version of the IntCal20 curve with a North-South hemispheric offset, estimated based upon periods of overlap in Northern and Southern tree ring determinations, of approximately $36 \pm 27(1 \sigma){ }^{14} \mathrm{C}$ yr. As shown in Figure 2, the ice core age and IntCal20-calibrated ${ }^{14} \mathrm{C}$ age agree considering their uncertainties. Nevertheless, the most likely age estimates differ by about 


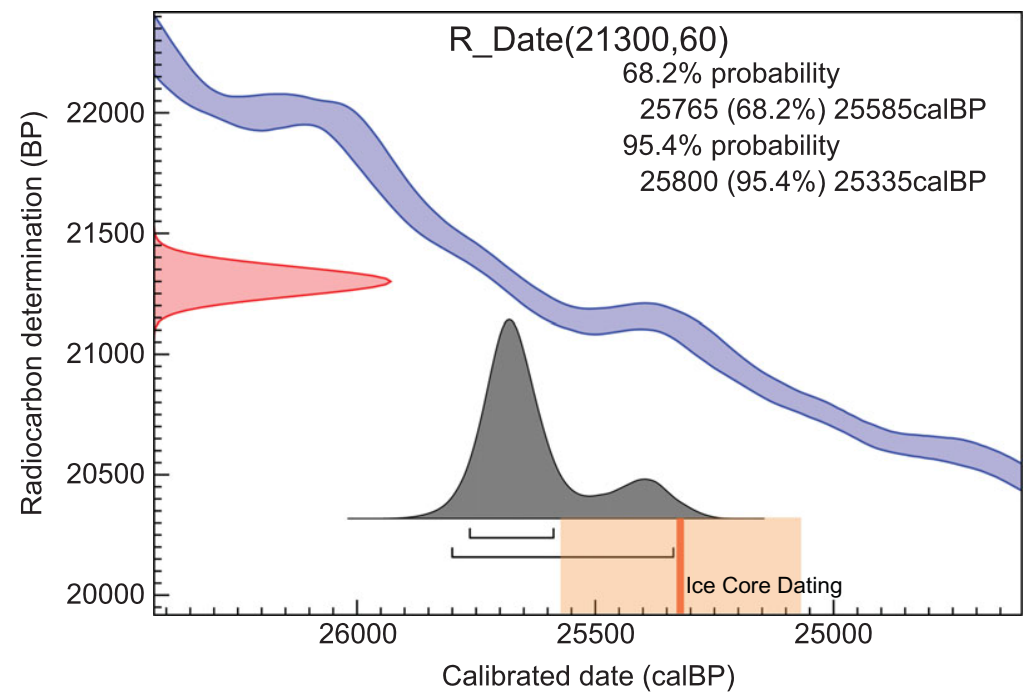

Figure 2 Calendar age of the Oruanui eruption calibrated with the SHCal20 calibration curve (Hogg et al. 2020 in this issue) in comparison to the ice core age in the WAIS divide ice core (Sigl et al. 2016; Dunbar et al. 2017).

350 years suggesting the WAIS ice-core time scale is showing younger ages around 25,500 calBP compared to the data underlying IntCal20.

\section{Campanian Ignimbrite, around 40,000 yr Ago}

The Campagnian Ignimbrite (CI) eruption in Southern Italy has been ${ }^{14} \mathrm{C}$ dated on charred wood embedded in the Yellow Tuff from the eruption (Giaccio et al. 2017). After removal of two outliers, possibly caused by incomplete removal of contaminations, 12 measurements on 7 samples yielded a weighted mean ${ }^{14} \mathrm{C}$ age of $34,290 \pm 90(1 \sigma){ }^{14} \mathrm{C} \mathrm{yr}$ BP for the eruption. The date of the $\mathrm{CI}$ eruption has been independently determined with the $\mathrm{Ar} / \mathrm{Ar}$ method (Giaccio et al. 2017). While the individual Ar/Ar dates span a relatively large age range from 38.2 to $41.4 \mathrm{Ar} / \mathrm{Ar}$ yr BP the weighted mean age has been determined to $39,850 \pm 140 \mathrm{Ar} / \mathrm{Ar}$ yr BP considering all known uncertainties and encompassing the 95\% confidence interval (Giaccio et al. 2017). Figure 3 compares this ${ }^{14} \mathrm{C}$-calendar age relationship to the IntCal20 calibration curve. Calibrating the ${ }^{14} \mathrm{C}$ age with $\mathrm{IntCa} 20$ yields a 2- $\sigma$ calendar age range from 39,705 to 39,220 calendar yr BP slightly underestimating the average $\mathrm{Ar} / \mathrm{Ar}$ age. It does suggest that the dating uncertainties (Ar/Ar and/or ${ }^{14} \mathrm{C}$ dating) are rather underestimated for this example. Alternatively, the IntCal20 calibration curve could exhibit a slight bias here.

In summary, the IntCal20 calibration curve is largely supported by these three examples of volcanic eruptions with very well determined ${ }^{14} \mathrm{C}$ ages combined with independent age assessments. Including these three data points as anchors into the construction of the calibration curve would not have changed the IntCal20 curve significantly. The value of this comparison rather relies in the possible detection of small biases in the IntCal20 curve which might not only be related to systematic offsets e.g. due to a slightly biased reservoir correction of the speleothem ${ }^{14} \mathrm{C}$ data. It might also be connected to the fact that much of the glacial part of IntCal20 does not capture all of the fine structure. This latter issue will 


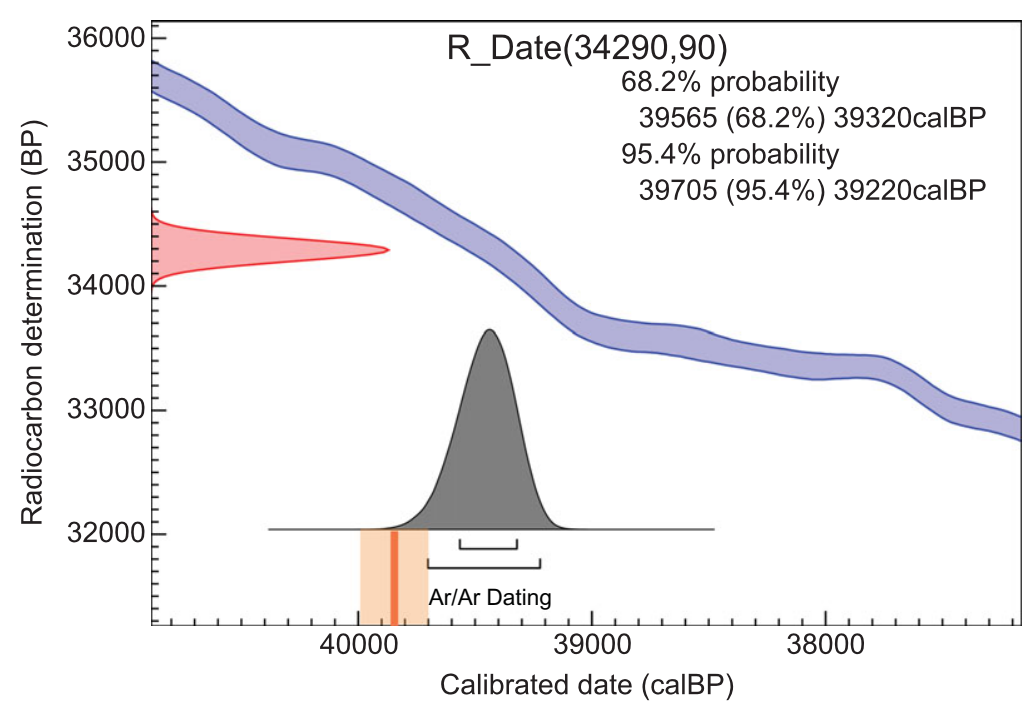

Figure 3 Calibrated ${ }^{14} \mathrm{C}$ age of the $\mathrm{CI}$ eruption compared to the $\mathrm{Ar} / \mathrm{Ar}$ age of $39,850 \pm 140$ calendar yr BP.

be further discussed in the next section where we compare highly resolved floating tree-ring ${ }^{14} \mathrm{C}$ data for the last glacial period that, however, are not directly independently dated.

\section{Floating Trees Connected to Ice-core Time Scales and Their Relationship to IntCal20}

As mentioned, the IntCal20 calibration curve is extended into the last glacial period with, compared to tree ring information, less direct data. This includes marine or speleothem data that do not directly reflect atmospheric ${ }^{14} \mathrm{C}$ levels and/or data that has larger uncertainties on their calendar age. This, together with a generally lower data resolution and larger ${ }^{14} \mathrm{C}$ measurement uncertainties, results in a smoother calibration curve prior to ca. 13,900 calendar yr BP.

There are two distinct causes for such increased smoothness, which should not be conflated. Firstly, it is key not to interpret the variability in plots of the IntCal20 mean curve (and probability intervals) as directly representative of our belief in the level of atmospheric variation at any time. Instead, the curve is designed to provide point-wise estimates of past ${ }^{14} \mathrm{C}$ levels to enable accurate calibration of single determinations-this is a subtle but critical difference. This is particularly relevant where the curve is based upon data with uncertain calendar ages as occurs throughout the glacial period; or where constituent data is highly sparse and provides limited information.

The IntCal20 curve is a point-wise mean summary of a large number of posterior realizations obtained via our Bayesian approach to curve creation (Heaton et al. 2020 in this issue). Each of these realizations represents a distinct plausible atmospheric ${ }^{14} \mathrm{C}$ history based upon the constituent data. Where these data have uncertain calendar ages, each of our Markov Chain Monte Carlo (MCMC) realizations will posit a particular set of potential true calendar ages for them and provide a plausible ${ }^{14} \mathrm{C}$ history on that basis. While each of these individual realizations may show a similar structure to one another, once the differing calendar ages at which that feature may occur are averaged over, it may appear less 
prominent in the summarized mean calibration curve. This effect is seen most simply when incorporating floating tree-ring sequences into the curve-here, each curve realization may have very similar levels of variation due to the known internal chronology but, once the uncertainty in the absolute age of the sequence is averaged over, it results in a reduced variation in the summarized mean. Similarly, during periods where little data is available on which to base the curve, the IntCal20 mean will tend towards interpolation and hence appear smooth. This should not be interpreted as a belief in atmospheric smoothness, rather that IntCal20 cannot resolve when any variation may have occurred due to limited information.

It is important to stress that this propagation of calendar age uncertainty in constituent data through to IntCal20 is what enables accurate calibration and hence a desired feature. For calibration of single determinations, the point-wise mean and associated uncertainty is sufficient to achieve this and provides the simplest representation of the curve. However, if modelling multiple highly resolved determinations, or if interest is in atmospheric variability, individual curve realizations may provide more insight.

Secondly, and more significant is that, due to the reduced density of data available in the glacial period, we may simply not observe some short-term atmospheric variation. In addition, since both marine records and speleothems provide indirect measurement of atmospheric ${ }^{14} \mathrm{C}$ via processes that may introduce potential smoothing of the atmospheric signal, we risk underestimating some atmospheric variations even if we can identify their existence. As a consequence, the curve may lack some structure that could, if included, provide multimodal calibrated ages for some radiocarbon ages. This issue has been illustrated by Adolphi et al. (2017) who showed that "floating" tree-ring sequences, i.e. tree-ring sequences without direct absolute age estimates, show ${ }^{14} \mathrm{C}$ structures that are not reflected in the previous calibration curve IntCal13 just prior to 13,900 calendar yr BP (Reimer et al. 2013). Such missing structure may have the effect that material from around 14,700 calendar yr BP could incorrectly be calibrated as 500 years more recent (Adolphi et al. 2017).

IntCal20 has aimed to address this by allowing for more variability in the calibration curve and by including the information from multiple floating tree-ring series even though they are not dated via dendrochronology. However, this does not remove the risk of similar missing structure in other regions of the calibration curve if the observations, on which we base the curve, do not exhibit the higher frequency components of the atmospheric variation. In the following we discuss the three sections in the calibration curve where floating tree-ring sequences have been used: the tree-ring sequences from around 14,700 calendar yr BP discussed above; as well as a kauri tree from New Zealand from around 30,000 calendar yr BP; and another NZ kauri from around 42,000 calendar yr BP. We compare the resultant curve in each time period to the original ${ }^{14} \mathrm{C}$ data from tree rings.

\section{Floating Tree-Ring Records around 14,700 yr Ago}

Adolphi et al. (2017) provide estimates, on the GICC05 ice-core timescale, of the absolute calendar ages of three floating tree-ring sequences from around 14,700 calendar yr BP. However, in order to keep independence between the creation of the IntCal20 timescale and the ice-core timescales, this prior knowledge was not used. Instead all three floating tree-ring sequences were incorporated into IntCal20 with uninformative priors on their absolute ages. Fitted posterior calendar ages were estimated internally during curve 


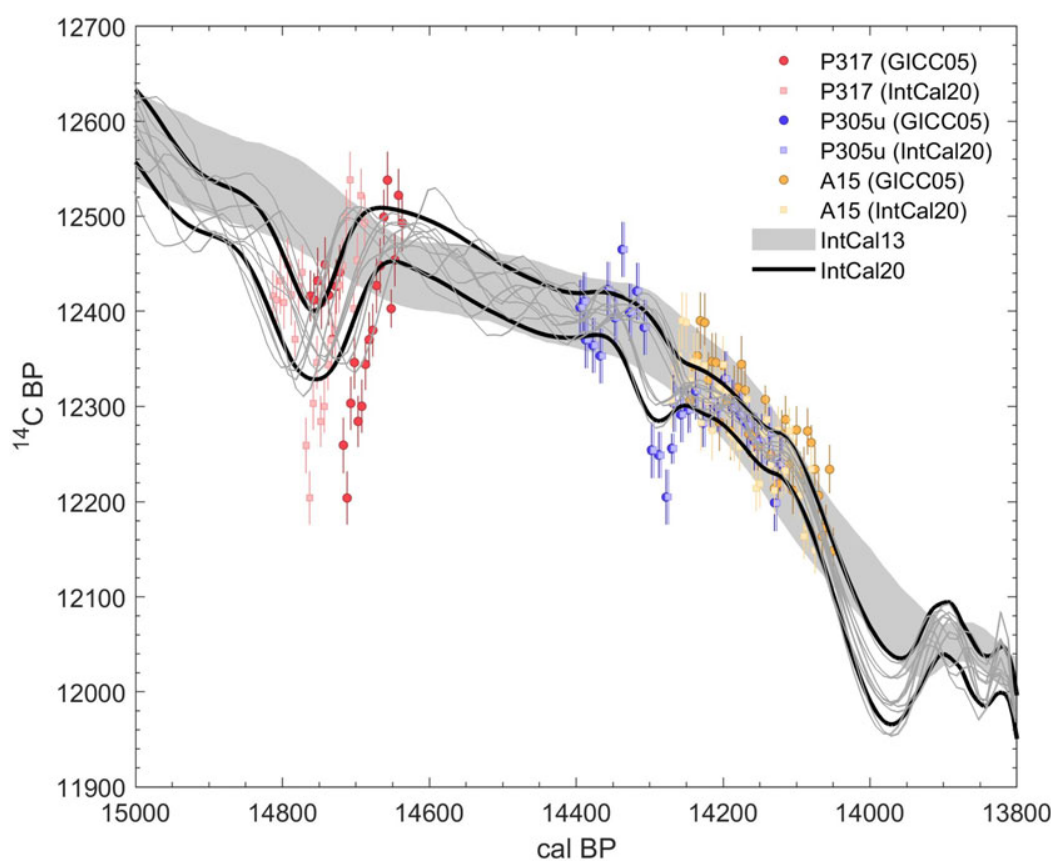

Figure 4 Comparison of IntCal13 (gray band) (Reimer et al. 2013), IntCal20 (black) (Reimer et al. 2020 in this issue) and the placement of the three floating tree-ring series according to Adolphi et al. (2017) (darker colors, "GICC05") and according to the best fit to the other data going into IntCal20 (lighter colors, "IntCal20"). Only data measured at ETH Zurich is shown. The gray lines show 10 individual realizations of the curves underlying IntCal20.

construction and entirely determined according to their fit to the rest of the IntCal20 ${ }^{14} \mathrm{C}$ data; see Heaton et al. (2020 in this issue) for details.

Maintenance of such independence between the timescales enables comparisons to be made between the calendar ages estimates of the various floating trees obtained during IntCal construction and the ice-core based estimates. Such comparisons provide useful information on the synchroneity of the ${ }^{14} \mathrm{C}$ and ice-core timescales as well as potential discrepancies worthy of further study.

The three floating tree-ring series have ${ }^{14} \mathrm{C}$ ages in the range from about 12,200 to $12,500{ }^{14} \mathrm{C} \mathrm{yr}$ BP (Adolphi et al. 2017). The possible calendar ages could be obtained via calibrating the data to the IntCal13 calibration curve. Additional information on possible placements can be obtained from ${ }^{10} \mathrm{Be}$ measurements in ice cores as ${ }^{14} \mathrm{C}$ and ${ }^{10} \mathrm{Be}$ are both cosmogenic isotopes produced by similar processes in the atmosphere. For this purpose the production signal inferred from the ice core ${ }^{10} \mathrm{Be}$ data can be translated into an atmospheric ${ }^{14} \mathrm{C}$ signal via carbon cycle modelling (Beer et al. 1988). Via the common production rate signal the floating ${ }^{14} \mathrm{C}$ records can be aligned with the ice-core time scale (Adolphi et al. 2017). Figure 4 shows the comparison of IntCal13, IntCal20 and the floating tree data according to the best placement inferred by Adolphi et al. (2017) (darker colors) and the floating ${ }^{14} \mathrm{C}$ records according to the best fit to the other data underlying IntCal20 (lighter colors). 
Figure 4 shows that IntCal20 captures more of the typical variability that we know from e.g. the Holocene period and that is indicated in the floating tree-ring data. From ice core ${ }^{10} \mathrm{Be}$ data we know that this typical production-related variability should also be present throughout the last glacial period (e.g. Wagner et al. 2001; Adolphi et al. 2014). Figure 4 also shows that the method to produce IntCal20 still leads to some smoothing, i.e. it reduces the amplitude of ${ }^{14} \mathrm{C}$ age-calendar age variations as shown by the tree-ring data. In part, this is likely a consequence of the presence of marine and speleothem based ${ }^{14} \mathrm{C}$ data in this time period and also used in IntCal20 construction. These are typically smoother and do not exhibit the same level of variation seen in the floating tree-ring sequences. However, we also observe the effect discussed earlier whereby the plotted IntCal20 mean curve has integrated the floating treering sequences over their range of potential calendar ages meaning the variability is reduced in the consequent point-wise summary. While the individual curve realizations obtained by the MCMC method retain more of the full structure of the tree-ring ${ }^{14} \mathrm{C}$ data the average of all curves does not since the time scale uncertainties lead to a smoothing in the averaging process. It is therefore recommended to use the individual IntCal realizations for solar activity or carbon cycle studies, but also for wiggle-matching of highly resolved sequences of ${ }^{14} \mathrm{C}$-dates, as their amplitudes better represent the real variability, at least during periods where the IntCal curve is based on sequences of high quality data with robust relative or incremental age control.

The inclusion of the floating tree-ring data into IntCal20 eliminates to a large extent possible calibration biases that one could possibly obtain using IntCal13. The large ${ }^{14} \mathrm{C}$ age drop and reversal around 14,700 calendar yr BP coincides with the rapid warming into the Bølling/ Allerød period corresponding to the Greenland Interstadial 1 (Rasmussen et al. 2006). The floating tree-ring data indicates that ${ }^{14} \mathrm{C}$ ages of $12,300{ }^{14} \mathrm{C}$ yr $\mathrm{BP}$ could be obtained for this climate transition. However, with IntCal13 the calibrated ages for this event would be about 500 years too young. Even though not capturing the complete amplitude of ${ }^{14} \mathrm{C}$ age variability, IntCal20 will likely lead to a non-zero calendar age probability around 14,750 calendar yr BP for such samples, especially considering that such samples typically have dating uncertainties larger than 50 years. We therefore recommend researchers to recalibrate and update their age models with IntCal20 in cases that the results critically depend on the ${ }^{14} \mathrm{C}$ dating of events between 14,000 and 15,000 years ago.

\section{Floating Tree-Ring Records around 30,000 yr Ago}

Turney et al. (2016) reported on a 2000-yr-long floating tree-ring ${ }^{14} \mathrm{C}$ record from kauri trees from New Zealand. The ${ }^{14} \mathrm{C}$ variations in this record could also be linked to ice core ${ }^{10} \mathrm{Be}$ data. However, the ice core dating around 30,000 calendar yr BP includes relatively large uncertainties since layer counted time scales add more uncertainty the longer the counted time scale is. The Greenland ice-core time scale (GICC05) contains about 1000 uncertain years around 30,000 calendar yr BP (Svensson et al. 2008). This implies that, even though an unequivocal link has been found, the direct transfer of the ice-core time scale to the floating tree-ring ${ }^{14} \mathrm{C}$ series does not help to improve the calibration curve. However, as for the three floating tree-ring sequences described in the previous section, the kauri data can be incorporated alongside the existing ${ }^{14} \mathrm{C}$ data from macrofossils, speleothems and foraminifera around this period in curve construction, simultaneously estimating their calendar ages using information from the other data. This permits us to add truly atmospheric and high resolution ${ }^{14} \mathrm{C}$ data to the calibration curve (Reimer et al. 2020 in this issue). This is of particular interest around 30,000 calendar yr BP since IntCal13 for 


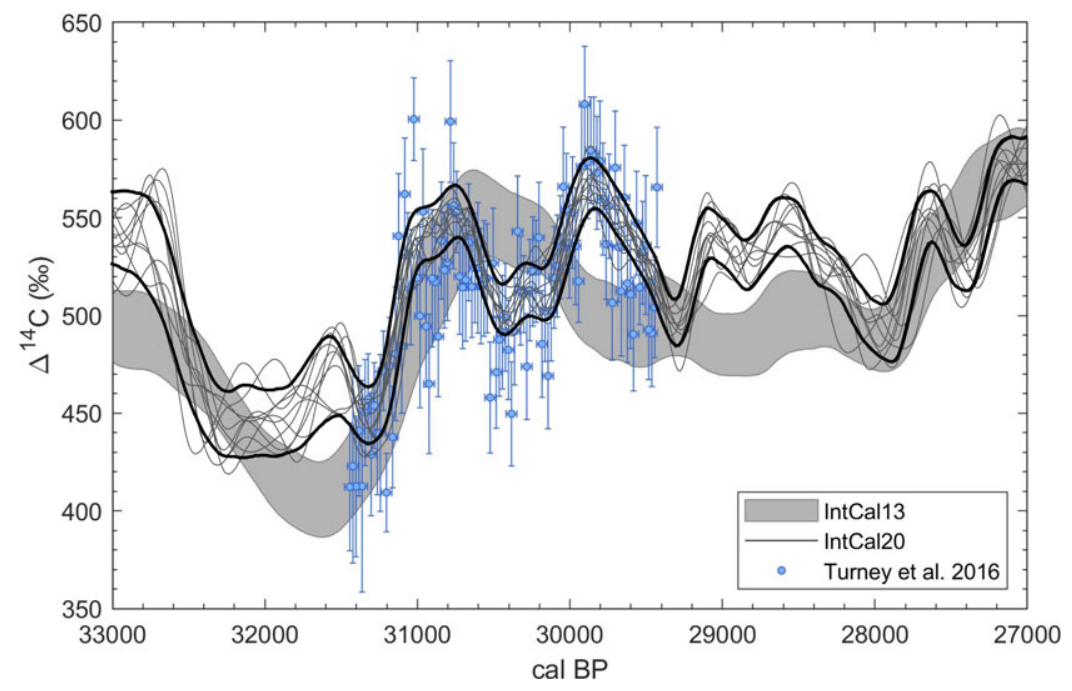

Figure 5 Atmospheric ${ }^{14} \mathrm{C}$ variability (expressed as per mille $\Delta{ }^{14} \mathrm{C}$, which is ${ }^{14} \mathrm{C} /{ }^{12} \mathrm{C}$ corrected for fractionation and decay relative to a standard, denoted $\Delta$ in Stuiver and Polach [1977]) around 30,000 calendar yr BP. The figure shows the comparison of IntCal13 (Reimer et al. 2013), IntCal20 (black lines, Reimer et al. 2020 in this issue) and the kauri $\Delta^{14} \mathrm{C}$ data (Turney et al. 2016) calibrated onto the ${ }^{14} \mathrm{C}$ data underlying IntCal20. The gray lines show 10 individual realizations of the curves going into IntCal20.

that period is based on strongly disagreeing data and largely followed the macrofossil data from Lake Suigetsu (Reimer et al. 2013). Since the publication of IntCal13, the calibration curve for this period has been confirmed by new ${ }^{14} \mathrm{C}$ data from speleothems from Hulu Cave in China (Cheng et al. 2018) and the floating kauri ${ }^{14} \mathrm{C}$ record agrees well with the latter two records (Figure 5).

\section{Floating Tree-Ring Records around 42,000 yr Ago}

Another, almost 1500 -yr-long, floating ${ }^{14} \mathrm{C}$ sequence from kauri trees with ${ }^{14} \mathrm{C}$ ages in the range of $40,000{ }^{14} \mathrm{C}$ yr BP (Mangawhai sequence) has been published by Turney et al. (2010). This floating chronology shows a relatively stable atmospheric $\Delta^{14} \mathrm{C}$ level for about 500 years that is followed by an increase in $\Delta^{14} \mathrm{C}$ of about 200 per mille over the subsequent 800 years. This feature is reminiscent of the increase in the production rates caused by the Laschamps geomagnetic field minimum (Muscheler et al. 2004). In fact, matching the ${ }^{14} \mathrm{C}$ structure from the floating trees with the ${ }^{10} \mathrm{Be}$ variations in the Greenland ice cores provided an ice core age of about 42,500 calendar yr BP for the start of the floating Mangawhai sequence which is about $1000 \mathrm{yr}$ younger than the placement according to the available independent ${ }^{14} \mathrm{C}$ calibration data around 43,500 calendar yr BP (Muscheler et al. 2014b) (Figure 6). This ${ }^{10} \mathrm{Be}$-based ice core placement has also been put into question by the new U/Th-dated speleothem data from Hulu Cave (Cheng et al. 2018) that leads to a good agreement between Hulu and kauri ${ }^{14} \mathrm{C}$ data when placing the tree ring chronology about 1000 years older. This, however, leads to differences between modeled ${ }^{10} \mathrm{Be}$-based atmospheric ${ }^{14} \mathrm{C}$ variability and measured ${ }^{14} \mathrm{C}$. Part of the differences can be attributed to ice-core time scale uncertainties that can, however, explain only about $250 \pm 250$ years of the difference (Adolphi et al. 2018). It rather appears that the ${ }^{10} \mathrm{Be}$-based ${ }^{14} \mathrm{C}$ and IntCal record show 


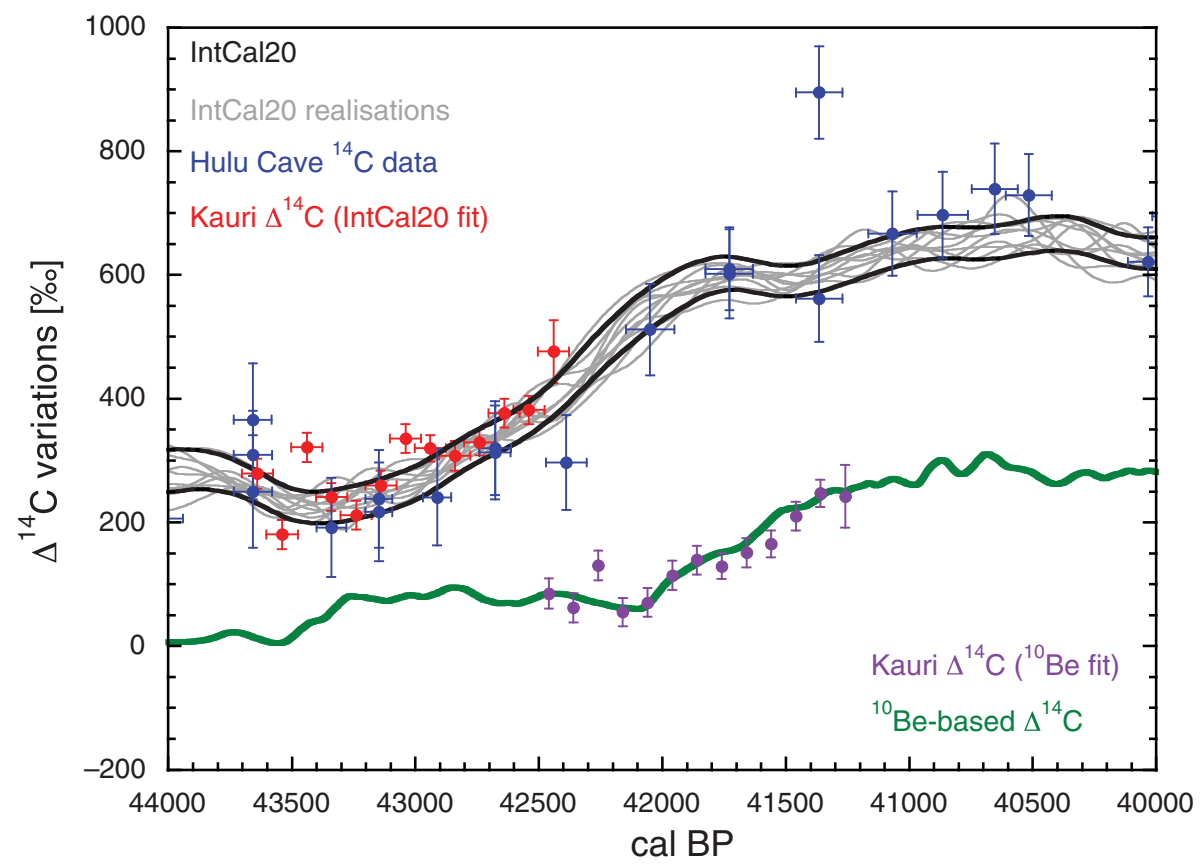

Figure 6 Comparison of IntCal20 (the two black lines indicate the 1- $\sigma$ range), Hulu Cave ${ }^{14} \mathrm{C}$ data (blue) and kauri ${ }^{14} \mathrm{C}$ data (red) according to the best placement with respect to the data underlying IntCal20. The lower panel shows the kauri ${ }^{14} \mathrm{C}$ data (purple) according to the best fit to the production signal as inferred from ${ }^{10} \mathrm{Be}$ in Greenland ice cores (green line; Muscheler et al. 2014b). The vertical offset between the two kauri placements is due to the different decay correction depending on the different age placements. The vertical placement of the modeled ${ }^{10} \mathrm{Be}$-based $\Delta^{14} \mathrm{C}$ depends on normalization and carbon cycle configuration, i.e. only the relative variations can be robustly interpreted. The gray lines show 10 individual realizations of the curves underlying IntCal20.

differences that are not only production related. For example, the amplitude of the atmospheric ${ }^{14} \mathrm{C}$ increase (expressed as $\Delta^{14} \mathrm{C}$ ) around Laschamps is larger in the ${ }^{14} \mathrm{C}$ data than in the modeled ${ }^{10} \mathrm{Be}$ record. Furthermore, the $\Delta^{14} \mathrm{C}$ increase starts earlier and lasts longer in the ${ }^{14} \mathrm{C}$ data compared to the changes indicated by the ice core ${ }^{10} \mathrm{Be}$ record. The most likely explanation for these differences is possible influences of the carbon cycle on atmospheric ${ }^{14} \mathrm{C}$. A reduced ocean uptake of ${ }^{14} \mathrm{C}$ can explain larger amplitudes of production-induced changes in $\Delta^{14} \mathrm{C}$ and possible changes in the carbon cycle could lead to ${ }^{14} \mathrm{C}$ variability that cannot be seen in ice core ${ }^{10} \mathrm{Be}$ data. Due to these reasons we conclude that the ice core placement of the floating kauri sequence is likely too young. As for the other floating treering sequences, this kauri data was incorporated into IntCal20 with an uninformative prior on its calendar age. Posterior calendar ages were estimated alongside curve construction according to fit to the rest of ${ }^{14} \mathrm{C}$ data. This approach placed the tree-ring sequence around 43,000 calendar yr BP and IntCal20 reflects features of the kauri data in this period.

\section{Time Scale Transfer between IntCal20 and Ice-Core Time Scales}

The radiocarbon (IntCal) time scale is of fundamental importance for assessing cultural and climatic changes in the correct temporal context. With respect to climate change the ice core records from Greenland and Antarctica provide the other key temporal context that is often 
used when assessing ${ }^{14} \mathrm{C}$ dated records in comparison to, for example, the rapid climate changes during the last glacial period. Presently, these two key time scales are based on different methods and the ice-core time scales (e.g. GICC05 or WD2014) do not directly enter into the context of creating an IntCal calibration curve. This, however, also implies that systematic offsets between the IntCal and the ice-core time scales can lead to a wrong assessment of temporal relationships unless potential systematic offsets between these time scales are corrected for. This issue can be addressed by identifying and synchronizing the common production rate variations, i.e. by using the signal from the global cosmic ray irradiation to compare ${ }^{14} \mathrm{C}$ and ice core radionuclide records. In the following we will review the results from this approach comparing the Greenland ice-core time scale (GICC05) with the IntCal20 time scale for the Holocene and the last glacial period, separately.

\section{Holocene}

The common production rate variations in ${ }^{14} \mathrm{C}$ (IntCal) and in ${ }^{10} \mathrm{Be}$ and ${ }^{36} \mathrm{Cl}$ (as measured in ice cores) can be directly compared only after correction for systematic differences due to the different geochemical behavior. Common variability, if correctly identified, can then be used to tie the ice-core time scale to the IntCal time scale or vice versa. For the Holocene period this task is rather straightforward. The ${ }^{14} \mathrm{C}$ variations are temporally well constrained via dendrochronology and the ${ }^{14} \mathrm{C}$ data are of generally high quality. Furthermore, it is rather straightforward to translate e.g. ${ }^{10} \mathrm{Be}$ variations in ice cores into atmospheric ${ }^{14} \mathrm{C}$ variability by using the ${ }^{10} \mathrm{Be}$ signal as production input for the ${ }^{14} \mathrm{C}$ modeling with carbon cycle models. Major changes in the carbon cycle are not expected and also the radionuclide signal in the ice cores is not very strongly affected by climatic changes. This comparison of ice core radionuclide data and ${ }^{14} \mathrm{C}$ in tree rings has led to a time scale transfer function that can be used to relate Greenland ice core data (on the GICC05 time scale (Vinther et al. 2006)) to ${ }^{14} \mathrm{C}$-dated records. It indicates that GICC05 has the tendency to accumulate too many years (about 65) over the Holocene period (Adolphi and Muscheler 2016; Muscheler et al. 2014a, the transfer function can be downloaded here: https://www.clim-past.net/12/15/2016/cp-12-15-2016-supplement.zip). In addition, the rapid ${ }^{14} \mathrm{C}$ increases around 774 and $993 \mathrm{AD}$ have lead to a very precise matching of ${ }^{14} \mathrm{C}$ and ice-core time scales for the past 2500 years which enabled the detailed comparison of volcanic forcing (as inferred from ice core sulfate data) and climate reaction (as inferred from tree-ring data) (see updated NS1-2011 Greenland chronology for the past 2500 years as discussed by Sigl et al. 2015). The same approach has shown that the WAIS divide ice-core time scale (WD2014) shows only very small deviations from the tree ring time scale for the past 11,000 years (Sigl et al. 2016). IntCal20 includes significantly more ${ }^{14} \mathrm{C}$ data for the Holocene period than IntCal13. This has mostly improved the fine structure for limited sections of the IntCal calibration curve (e.g. the most recent 1000 years). However, the underlying tree-ring time scale has not changed for the Holocene period and, therefore, we do not expect that the time scale transfer function will deviate significantly for IntCal20 compared to IntCal13.

\section{Ice Age}

The linking of ice core and IntCal time scale is much more challenging for the last glacial period. On the one hand the ice core ${ }^{10} \mathrm{Be}$ and ${ }^{36} \mathrm{Cl}$ data can be influenced by atmospheric circulation and deposition changes which are not always easy to identify and correct for. Similarly, carbon cycle changes could potentially influence the atmospheric ${ }^{14} \mathrm{C}$ 
concentration much more than during the Holocene. Furthermore, IntCal20 is the product of a combination of a range of data sets so that the origin of ${ }^{14} \mathrm{C}$ variability might not always be robustly identifiable. For example, periodic offsets between differing data sets could lead to oscillations in IntCal in between the data, i.e. lead to structures that are not present in any data set alone. Furthermore, as mentioned above, the ${ }^{14} \mathrm{C}$ data has lower resolution and larger uncertainties making it more challenging to identify production rate variations in the data.

For the period preceding 13,910 cal $\mathrm{BP}$, where the continuous tree-ring ${ }^{14} \mathrm{C}$ data on their own become insufficient to estimate the curve precisely, the time scale of the IntCal20 calibration curve is largely based upon ${ }^{14} \mathrm{C}$ measurements on U/Th-dated samples. While this is clear for the case of the directly U/Th-dated samples such as corals and speleothems, it also applies to data seemingly not directly connected to U/Th dating. The atmospheric (macrofossil) samples from Lake Suigetsu cannot solely be dated via varve counting since not all sections of the sediments show well-identifiable varves. Therefore, to obtain their calendar ages, the ${ }^{14} \mathrm{C}$ data from Lake Suigestsu has partly also been "wiggle-matched" to U/Th-dated ${ }^{14} \mathrm{C}$ data from Hulu Cave (Bronk Ramsey et al. 2012, 2020 in this issue). Calendar age estimates for the non-varved sections from the Cariaco basin and the Iberian and Pakistan margin cores were obtained from stratigraphic tuning of palaeoclimate proxies to the high resolution and precisely U/Th dated $\delta^{18} \mathrm{O}$ Hulu Cave record (Bard et al. 2013; Heaton et al. 2013; Hughen and Heaton 2020 in this issue).

Adolphi et al. (2018), therefore, took the approach to compare the Greenland radionuclide records to the individual records underlying IntCal to assess the temporal relationship between Greenland ice-core time scale (GICC05) and the U/Th time scale underlying IntCal. Starting from the tree-ring-based data, where no significant time scale offsets can be observed around 13,000 cal BP, there are two additional distinct features that can be used for this time scale comparison. One is situated around 22,000 calendar yr BP possibly related to a longer lasting solar minimum or a period of decreased geomagnetic dipole field intensity. The other one is related to the Laschamps geomagnetic field minimum around 42,000 calendar yr BP. In between these fixed points, the time scale offset can be assessed with a Bayesian approach by including the ice core layer counting uncertainty (Figure 7; Adolphi et al. 2018). Since the study of Adolphi et al. (2018) additional U/Th-dated ${ }^{14} \mathrm{C}$ data from the Hulu Cave speleothems has been published (Cheng et al. 2018). These new data do not significantly affect the time scale transfer function as the new Hulu data support the results by Adolphi et al. (2018) within uncertainties (see yellow markers in Figure 7).

The volcanic time markers mentioned above also support the transfer function. The dating of Towada-H around around 15,700 calendar yr BP shows agreement between IntCal and GICC05 within uncertainty but it might hint at a 100 yr too young GICC05 age. Also, the transfer function shown in Figure 7 suggests a potential underestimation of the ice core age of the eruption. Oruanui cannot be discussed in this context since its tephra has only been found in an Antarctic ice core. However, in the GISP2 ice core a $\mathrm{SO}_{4}$ spike (depth between 2252-2252.2 $\mathrm{m}$ in the GISP2 ice core) has tentatively been attributed to the CI eruption. If correctly assigned it supports the agreement of GICC05 and IntCal around 40,000 calendar yr BP (Fedele et al. 2007; Giaccio et al. 2017). 


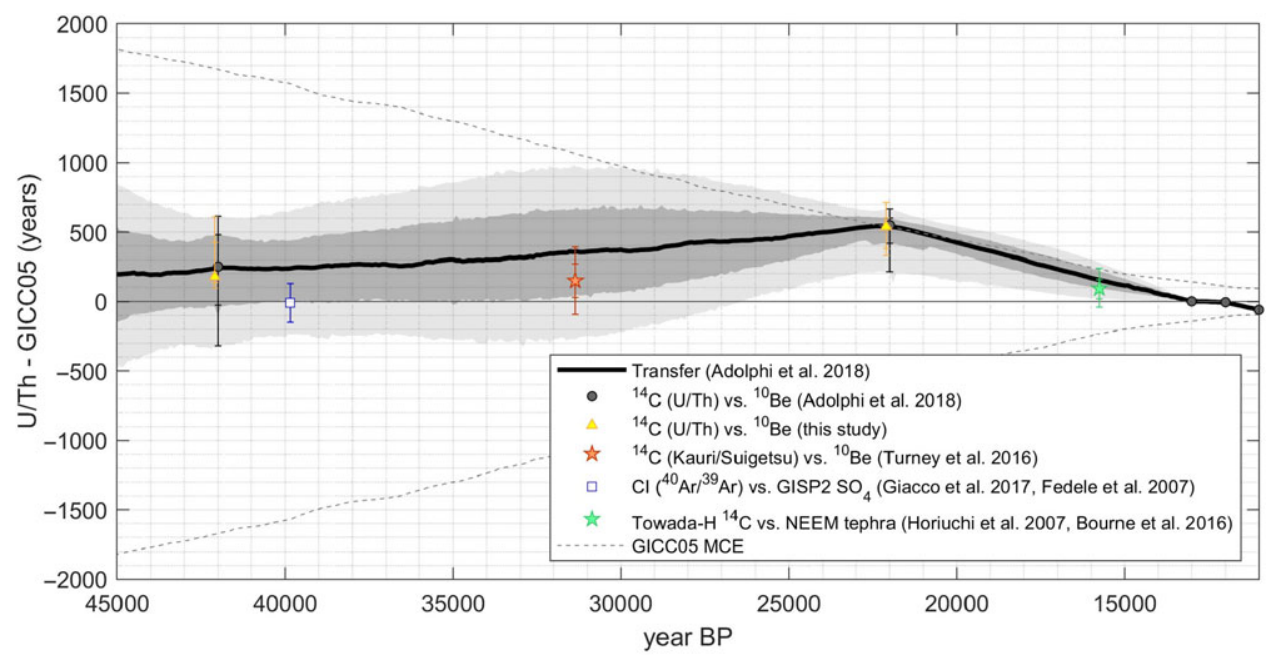

Figure 7 Time scale transfer function between U/Th-dated ${ }^{14} \mathrm{C}$ data (effectively the IntCal20 time scale) and the Greenland ice-core time scale (GICC05, Svensson et al. 2008). In black is the time scale transfer-function with the uncertainties in dark gray $(1 \sigma)$ and light gray $(2 \sigma)$. The maximum Holocene offset of 65 years is visible to the right at 11,500 calendar yr BP. Modified from Adolphi et al. (2018). We note, that the attribution of the $\mathrm{SO}_{4}$ peak in GISP2 to CI is purely based on the chronological agreement within uncertainties, and hence, tentative. The yellow markers show the time scale offsets inferred from the comparison of ice core radionuclide data and the Hulu Cave ${ }^{14} \mathrm{C}$ data including the new data published by Cheng et al. (2018).

These results effectively provide a time scale transfer-function between GICC05 and IntCal20 provided that the link between ${ }^{14} \mathrm{C}$ age and calendar age is accurate (for example, slight offsets in the speleothem reservoir correction affecting IntCal20 would still remain when comparing ${ }^{14} \mathrm{C}$-dated records with the ice-core time scale). In spite of such possibly un-quantified remaining uncertainties, this time-scale transfer should be considered when ${ }^{14} \mathrm{C}$-dated records and the Greenland ice core data on the GICC05 time scale are compared. The time-scale comparison/transfer function can be downloaded from the supplemental materials for Adolphi et al. (2018).

\section{SUMMARY}

The global cosmic-ray signal and/or widely spread volcanic deposition signals can be used to compare and synchronize different time scales. For IntCal20 this information provides valuable information that can be used for assessing the reliability of the calibration curve. This information largely supports IntCal20 and, in addition, it allows the assessment of systematic time scale offsets between ${ }^{14} \mathrm{C}$-dated and ice core records. This information is crucial for a reliable assessment of environmental changes when such records are compared. The published IntCal20 mean curve (and probability intervals) represent the point-wise summary of many possible realizations of the ${ }^{14} \mathrm{C}$ age-calendar age relationship in the past. These summary values are designed to enable accurate calibration of single sample determinations, however, they do not necessarily reflect atmospheric variation with the process of averaging leading to some smoothing in the point-wise mean curve. It is therefore recommended to use the individual IntCal20 realizations for solar activity and/or carbon cycle studies as their amplitudes better represent the real variability. Ongoing and 
future work on tree-ring ${ }^{14} \mathrm{C}$ measurements for the last glacial period on, for example, kauri trees has the potential to reduce the calibration uncertainties significantly. Such data can eliminate the presently still required reservoir age corrections of speleothem and marine ${ }^{14} \mathrm{C}$ data and reduce the relatively large uncertainties of the atmospheric data from the Suigetsu macrofossil record. Similarly, improved ice-core dating and a better understanding of the climate influences on radionuclide data will allow us to better pinpoint the presently existing differences between ice core and IntCal time scales. High-quality ${ }^{14} \mathrm{C}$ data together with Greenland and Antarctic radionuclide data have the potential to create a globally consistent time scale enabling robust investigations of archeology, evolution, regional climate change and their interactions in a global context.

\section{ACKNOWLEDGMENTS}

This work was supported by the Swedish Research Council (grant DNR2013-8421 to RM). FA was supported through a grant by the Swedish Research Council (Vetenskapsrådet no. 2016-00218). TJH was supported by the Leverhulme Trust (RF-2019-14019). CBR was partially supported through the UK Natural Environment Research Council (NERC) Radiocarbon Facility (NRCF010002).

\section{REFERENCES}

Adolphi F, Muscheler R. 2016. Synchronizing the Greenland ice core and radiocarbon timescales over the Holocene - Bayesian wiggle-matching of cosmogenic radionuclide records. Climate of the Past 12:15-30.

Adolphi F, Muscheler R, Svensson A, Aldahan A, Possnert G, Beer J, Sjolte J, Bjorck S, Matthes K, Thieblemont R. 2014. Persistent link between solar activity and Greenland climate during the Last Glacial Maximum. Nature Geoscience 7(9):662-666.

Adolphi F, Muscheler R, Friedrich M, Güttler D, Wacker L, Talamo S, Kromer B. 2017. Radiocarbon calibration uncertainties during the last deglaciation: Insights from new floating tree-ring chronologies. Quaternary Science Reviews 170:98-108.

Adolphi F, Bronk Ramsey C, Erhardt T, Edwards RL, Cheng H, Turney CSM, Cooper A, Svensson A, Rasmussen SO, Fischer H, et al. 2018. Connecting the Greenland ice-core and U-Th timescales via cosmogenic radionuclides: Testing the synchroneity of Dansgaard-Oeschger events. Climate of the Past 14:1755-1781. doi: 10.5194/ cp-14-1755-2018.

Bard E, Ménot G, Rostek F, Licari L, Böning P, Edwards RL, Cheng H, Wang Y, Heaton TJ. 2013. Radiocarbon calibration/comparison records based on marine sediments from the Pakistan and Iberian margins. Radiocarbon 55(4):1999-2019.

Beer J, Siegenthaler U, Bonani G, Finkel RC, Oeschger H, Suter M, Wölfli W. 1988.
Information on past solar activity and geomagnetism from ${ }^{10} \mathrm{Be}$ in the Camp Century ice core. Nature 331:675-679.

Bourne AJ, Abbott PM, Albert PG, Cook E, Pearce NJG, Ponomareva V, Svensson A, Davies SM. 2016. Underestimated risks of recurrent longrange ash dispersal from northern Pacific Arc volcanoes. Scientific Reports 6(1):29837.

Bronk Ramsey C, Staff RA, Bryant CL, Brock F, Kitagawa $H$, van der Plicht J, Schlolaut G, Marshall MH, Brauer A, Lamb HF, et al. 2012. A complete terrestrial radiocarbon record for 11.2 to $52.8 \mathrm{kyr}$ B.P. Science 338(6105): 370-374.

Bronk Ramsey C, Heaton TJ, Schlolaut G, Staff RA, Bryant CL, Brauer A, Lamb HF, Marshall MH, Nakagawa T. 2020. Reanalysis of the atmospheric radiocarbon calibration record from Lake Suigetsu, Japan. Radiocarbon 62. This issue. doi: 10.1017/RDC.2020.18.

Cheng H, Edwards RL, Southon J, Matsumoto K, Feinberg JM, Sinha A, Zhou W, Li H, Li X, $\mathrm{Xu}$ Y, et al. 2018. Atmospheric ${ }^{14} \mathrm{C} /{ }^{12} \mathrm{C}$ changes during the last glacial period from Hulu Cave. Science 362:1293-1297.

Dunbar NW, Iverson NA, Van Eaton AR, Sigl M, Alloway BV, Kurbatov AV, Mastin LG, McConnell JR, Wilson CJN. 2017. New Zealand supereruption provides time marker for the Last Glacial Maximum in Antarctica. Scientific Reports 7(1):12238.

Fedele FG, Giaccio B, Isaia R, Orsi G, Carroll M, Scaillet B. 2007. The Campanian Ignimbrite 
factor: towards a reappraisal of the Middle to Upper Palaeolithic "transition". In: Grattan J, Torrence R, editors. Living under the shadow: Cultural impacts of volcanic eruptions. New York: Left Coast Press. p. 19-41.

Giaccio B, Hajdas I, Isaia R, Deino A, Nomade S. 2017. High-precision ${ }^{14} \mathrm{C}$ and ${ }^{40} \mathrm{Ar} /{ }^{39} \mathrm{Ar}$ dating of the Campanian Ignimbrite $(\mathrm{Y}-5)$ reconciles the time-scales of climatic-cultural processes at 40 ka. Scientific Reports 7:45940. doi: 10.1038/ srep45940.

Heaton TJ, Bard E, Hughen KA. 2013. Elastic tiepointing - Transferring chronologies between records via a Gaussian process. Radiocarbon 55:1975-1997. doi: 10.2458/azu_js_rc.55.17777.

Heaton TJ, Blaauw M, Blackwell PG, Bronk Ramsey C, Reimer P, Scott EM. 2020. The IntCal20 approach to radiocarbon calibration curve construction: A new methodology using Bayesian splines and errors-invariables. Radiocarbon 62. This issue. doi: 10 . 1017/RDC.2020.46.

Hogg A, Heaton TJ, Hua Q, Bayliss A, Blackwell PG, Boswijk G, Ramsey CB, Palmer J, Petchey F, Reimer P, et al. 2020. SHCAL20 Southern Hemisphere calibration, 0-55,000 years cal BP. Radiocarbon 62. This issue. doi: 10.1017/RDC. 2020.59.

Horiuchi K, Sonoda S, Matsuzaki H, Ohyama M. 2007. Radiocarbon analysis of tree rings from a 15.5-cal kyr BP pyroclastically buried forest: A pilot study. Radiocarbon 49(2):1123-1132.

Hughen KA, Heaton TJ. 2020. Updated Cariaco Basin ${ }^{14} \mathrm{C}$ calibration dataset from $0-60 \mathrm{cal} \mathrm{kyr}$ BP. Radiocarbon 62. This issue. doi: 10.1017/ RDC.2020.53.

Muscheler R, Adolphi F, Knudsen MF. 2014a. Assessing the differences between the IntCal and Greenland ice-core time scales for the last 14,000 years via the common cosmogenic radionuclide variations. Quaternary Science Reviews 106:81-87.

Muscheler R, Adolphi F, Svensson A. 2014b. Challenges in ${ }^{14} \mathrm{C}$ dating towards the limit of the method inferred from anchoring a floating tree ring radiocarbon chronology to ice core records around the Laschamp geomagnetic field minimum. Earth and Planetary Science Letters 394:209-215.

Muscheler R, Beer J, Wagner G, Laj C, Kissel C, Raisbeck GM, Yiou F, Kubik PW. 2004. Changes in the carbon cycle during the last deglaciation as indicated by the comparison of ${ }^{10} \mathrm{Be}$ and ${ }^{14} \mathrm{C}$ records. Earth and Planetary Science Letters 219:325-340.

Rasmussen SO, Abbott PM, Blunier T, Bourne AJ, Brook E, Buchardt SL, Buizert C, Chappellaz J,
Clausen HB, Cook E, et al. 2013. A first chronology for the North Greenland Eemian Ice Drilling (NEEM) ice core. Climate of the Past 9(6):2713-2730.

Rasmussen SO, Andersen KK, Svensson AM, Steffensen JP, Vinther BM, Clausen HB, Siggaard-Andersen M-L, Johnsen SJ, Larsen LB, Dahl-Jensen D, et al. 2006. A new Greenland ice core chronology for the last glacial termination. Journal of Geophysical Research 111:D06102. doi: 10.1029/2005JD006079.

Reimer P, Bard E, Bayliss A, Beck JW, Blackwell PG, Bronk Ramsey C, Buck CE, Cheng H, Edwards RL, Friedrich M, et al. 2013. IntCal13 AND Marine13 radiocarbon age calibration curves 0-50,000 years cal BP. Radiocarbon 55(4):1869-1887.

Reimer PJ, Austin WEN, Bard E, Bayliss A, Blackwell PG, Bronk Ramsey C, Butzin M, Cheng $\mathrm{H}$, Edwards RL, Friedrich $\mathrm{M}$, et al. 2020. The IntCal20 Northern Hemisphere radiocarbon age calibration curve $(0-55 \mathrm{kcal}$ BP). Radiocarbon 62. This issue. doi: 10.1017/ RDC.2020.41.

Sigl M, Winstrup M, McConnell JR, Welten KC, Plunkett G, Ludlow F, Büntgen U, Caffee M, Chellman N, Dahl-Jensen D, et al. 2015. Timing and climate forcing of volcanic eruptions for the past 2,500 years. Nature 523:543-439.

Sigl M, Fudge TJ, Winstrup M, Cole-Dai J, Ferris D, McConnell JR, Taylor KC, Welten KC, Woodruff TE, Adolphi F, et al. 2016. The WAIS Divide deep ice core WD2014 chronology - Part 2: Annual-layer counting (0-31 ka BP). Climate of the Past 12:769-786.

Stuiver M, Polach HA. 1977. Discussion: Reporting of ${ }^{14} \mathrm{C}$ data. Radiocarbon 19(3):355-363.

Svensson A, Andersen KK, Bigler M, Clausen HB, Dahl-Jensen D, Davies SM, Johnsen SJ, Muscheler R, Parrenin F, Rasmussen SO, et al. 2008. A 60000 year Greenland stratigraphic ice core chronology. Climate of the Past 4:47-57.

Turney CSM, Fifield LK, Hogg AG, Palmer JG, Hughen K, Baillie MGL, Galbraith R, Ogden J, Lorrey A, Tims SG, et al. 2010. The potential of New Zealand kauri (Agathis australis) for testing the synchronicity of abrupt climate change during the Last Glacial Interval (60,000-11,700 years ago). Quaternary Science Reviews 29(27-28):3677-3682.

Turney CSM, Palmer J, Bronk Ramsey C, Adolphi F, Muscheler R, Hughen KA, Staff RA, Jones RT, Thomas ZA, Fogwill CJ, et al. 2016. High-precision dating and correlation of ice, marine and terrestrial sequences spanning Heinrich Event 3: Testing mechanisms of 
interhemispheric change using New Zealand ancient kauri (Agathis australis). Quaternary Science Reviews 137:126-134.

Vandergoes MJ, Hogg AG, Lowe DJL, Newnham RM, Denton GH, Southon J, Barrell DJA, Wilson CJN, McGlone MS, Allan ASR, et al. 2013. A revised age for the Kawakawa/Oruanui tephra, a key marker for the Last Glacial Maximum in New Zealand. Quaternary Science Reviews 74:195-201. doi: 10.1016/j.quascirev. 2012.11.006.
Vinther BM, Clausen HB, Johnsen SJ, Rasmussen SO, Andersen KK, Buchardt SL, Dahl-Jensen D, Seierstad IK, Siggaard-Andersen M-L, Steffensen JP, et al. 2006. A synchronized dating of three Greenland ice cores throughout the Holocene. Journal of Geophysical Research 111:D13102. doi: 10.1029/2005JD006921.

Wagner G, Beer J, Masarik J, Muscheler R, Kubik PW, Mende W, Laj C, Raisbeck GM, Yiou F. 2001. Geophysical Research Letters 28(2):303-306. 